\title{
Retracted article: Evaluation of Anammox activity in zeolite biofilter system
}

\author{
Kozet Yapsakli • Bulent Mertoglu
}

Received: 17 February 2010/ Accepted: 12 May 2010/Published online: 25 May 2010

(C) Springer Science+Business Media B.V. 2010

This article has been published OnlineFirst, but is withdrawn on request of the authors.

This article has been published OnlineFirst, but is withdrawn on request of the authors.

K. Yapsakli $(\bowtie)$

Environmental Engineering Department,

Faculty of Engineering, Marmara University,

Göztepe, Istanbul, Turkey

e-mail: kyapsakli@marmara.edu.tr

B. Mertoglu

Bioengineering Department, Faculty of Engineering,

Marmara University, Göztepe, Istanbul, Turkey

e-mail: bulent.mertoglu@marmara.edu.tr 